\title{
Vliv statických a dynamických protahovacích cvičení na rozsah kloubní pohyblivosti
}

\section{Effect of static and dynamic stretching on the range of motion}

\author{
Hana Kabešová, Štefan Balkó \\ Pedagogická fakulta UJEP v Ústínad Labem
}

\begin{abstract}
Abstrakt
Cílem studie bylo ověrit vliv statického a dynamického způsobu protahování hamstringů u probandů studující tělesnou výchovu a sport na PF UJEP. Flexibilita byla diagnostikována prostřednictvím modifikované Lassegueovy zkoušky (SLR). V předkládané studii byl sledován rozdíl mezi dosaženými úhly zadní strany stehna u dominantní dolní končetiny před aplikací a po aplikaci statických a dynamických protahovacích cvičení pomocí SLR provedené švihem nebo tahem. Pro sběr dat bylo využito videozáznamu (2D), který byl zpracován softwarem Dartfish Team Pro Data. Pomocí tohoto programu byly hodnoty úhlu převedeny na vzdálenost v centimetrech a vyhodnoceny. Výsledky prokázaly, že nebyly zjištěny statisticky významné rozdíly v hodnotách ROM prì pưsobení statického a dynamického zpưsobu protahování. Signifikantní rozdíly se však projevily mezi výchozím a výsledným úhlem dominantní dolní končetiny při působení dynamického strečinku, kde byl u SLR pohyb proveden švihem.
\end{abstract}

\begin{abstract}
The aim of the study was to assess the effect of static and dynamic way of stretching the hamstrings in probands studying physical education and sport at UJEP. Flexibility was diagnosed through a modified Lassegueovy test (SLR). In the present study, we evaluated the differences between the angles of the back of the thigh in the dominant lower limb before and after the application of static and dynamic stretching exercises performed using SLR push or pull. For data collection were used video (2D), which was developed software Dartfish Team Pro Data. With this program were converted to values of the angle distance in centimeters and evaluated. The results showed that there were no significant differences in ROM when exposed to static and dynamic stretching method. Significant differences, however, showed between the initial and final angle dominant lower limb when exposed to dynamic stretching, where the movement was executed swing.
\end{abstract}

Klíčová slova: kloubní rozsah pohybu, hamstringy, cviky pohyblivosti.

Key words: range of motion, hamstrings, stretching exercise.

\section{ÚVOD}

Rozcvičení je nedílnou součástí cvičební jednotky sportujících jedinců. Při přípravě před sportovním výkonem je rozcvičení doporučováno pro prevenci zranění i ke zlepšení samotného sportovního výkonu (Roi \& Bianchedi, 2008). Bartůňková (2007) zmiňuje, že rozcvičení stimuluje somatické a vegetativní funkce, které souvisí s úpravou funkčního stavu CNS, optimalizací dráždění CNS a vyšší efektivitu práce svalů. Přiměřená intenzita a trvání rozcvičení může způsobit metabolické, oběhové i nervové změny v organismu. Podle Máčka a Radvanského (2011) můžeme sledovat pozitivní efekt rozcvičení na úrovni 40-60\% následné zátěže. S ohledem na dobu potřebnou pro protažení svalu uvádějí Bandy a Irion (1994), že třicetivteřinové protažení dvouhlavého svalu stehenního mělo stejný efekt jako protažení minutové. Dostupné výzkumy však poukazují 
na odlišné efekty různých forem rozcvičení na sportovní výkon (Shier, 2004). Zkoumanou otázkou v metodice pohyblivosti je míra účinnosti intervence cvičení statických a dynamických.

Terminologie pojmu strečink je v současné době nejednotná. Někteří autoři překládají termín „stretching“ volně a široce jako proces protahování a jako veškerá protahovací cvičení, kterými lze dosáhnout zvýšení rozsahu kloubní pohyblivosti. Př́ikladem je členění podle Buzkové (2006), která řadí mezi základními druhy strečinku strečink aktivní, pasivní, statický, dynamický, metodu PIR (postizometrická relaxace) a PIP (postizometrické protažení), mezi dalšími druhy strečink rytmický, balistický a repetitivní, power stretch (silový strečink) a PNF (proprioceptivní neuromuskulární facilitaci). Obdobně člení strečink Alter (1999) na statický, dynamický, pasivní, aktivní strečink a proprioceptivní nervosvalovou facilitaci. Cvičení pro rozvoj kloubní pohyblivosti v souvislosti se strečinkem rozděluje Novotná (2006) na dynamický strečink - aktivní dynamická cvičení, statický strečink - aktivní statická cvičení, pasivní strečink - pasivní dynamická cvičení, aktivní strečink - pasivní statická cvičení. Z hlediska druhu pohybového programu je strečink definován v užším pojetí jako soubor speciálně prováděných protahovacích cvičení.

Podle způsobu protahování z hlediska působení sil zajištujících dosažení krajní polohy se člení pohyblivost na aktivní a pasivní a podle dynamiky provedení pohybu na dynamickou nebo statickou pohyblivost (Alter, 1999; Havel \& Hnízdil, 2010; Novotná, 2006; Ylinen, 2008).

U statického strečinku jde o rozsah pohybu v kloubu, kterého lze dosáhnout povlovným pomalým pohybem, někdy se uvádí výdrž v krajních polohách (avšak ne do bolesti). Zaujetí žádoucí polohy je pomalé, aby nedošlo k aktivaci strečového reflexu (Havel \& Hnízdil, 2010).

Statická metoda strečinku značí postupné natažení svalu až do krajní polohy a její udržení. Rozlišují se tři stupně protažení - mírné protažení („easy stretch“), rozvíjející protažení („developmental stretch“) a drastické protažení („drastic stretch“), ke kterému by nemělo dojít. Dýchá se bez apnoických pauz (Šebej, 2001).

Pro strečink založený na postfacilitačním útlumu je charakteristické, že se sval nejprve kontrahuje, pak uvolní a protáhne do krajní polohy rozsahu pohybu (Nelson \& Kokkonen, 2009). V PNF metodě podle Sölveborna se k utlumení napínacího reflexu využívá útlumu způsobeného podrážděním Golgiho šlachových receptorů silným izometrickým napnutím svalu.

U dynamického strečinku se jedná o protažení, ke kterému dochází při výkonu specifického sportovního pohybu (Nelson \& Kokkonen, 2009). Je obvykle spojován se skoky a odrazy, kdy je ke zvýšení rozsahu pohybu použito tzv. pohybové energie trupu či končetin (Alter, 1999). Hnací silou pohybu těla je pohybová energie. Zaujetí žádoucí polohy je vědomé, opakované a kontrolované. Jedná se o pohyb vedený, bez švihu a hmitu, přičemž dochází k postupnému zvětšování rozsahu, avšak ne v maximálním rozsahu a ne s velkým zrychlením.

Vedle dynamické pohyblivosti Alter (1999) použivá pojem funkční pohyblivost, která využívá rozsah kloubní pohyblivosti při provádění tělesné činnosti normální či zvýšenou rychlostí, avšak nezahrnuje skoky.

V řadě sportů se uplatňují švihové pohyby, např. v klasickém baletu, krasobruslení, výrazovém tanci, moderní i sportovní gymnastice, kde mají tyto pohyby navíc podstatný koordinační význam. Švihový (balistický) pohyb začíná rychlým, krátkým svalovým stahem, který je v krajní poloze zastaven mohutným stahem antagonistů. Ve vnitřní struktuře časového uspořádání rozlišují Tůma, Appelt, Libra, a Libra (1988) tři fáze: př́ípravná - příprava, nasazení pohybu; hlavní - maximální impulsivní svalové úsilí; závěrečná - doznívání, dokončení hlavní fáze, svalové úsilí bez impulsů; při opakování švihových pohybů je zároveň fází přípravnou. Průběh švihového pohybu je založen na mechanismu impulsu a je ovlivňován stř́idavým účinkem sil vnitřních a vnějších. Švihem mohou být provedeny pohyby částí těla i celého těla. Švihové pohyby probíhají vždy nerovnoměrnou rychlostí a z hlediska rytmicko-metrických zvláštností je lze provést pouze v určitém časovém a prostorovém rozměru, který je dán strukturou pohybu (Mihule \& Štastná, 1993). Např́íklad v rytmické gymnastice jsou cviky provedené švihem součástí techniky pohybu a daným provedením prvku obtížnosti. Ve sportovní přípravě mají švihová cvičení i jiný účel, ovlivnění pohyblivosti je pouze jedním z důsledků. 
V kondiční gymnastice se využívají hmity v krajní poloze, někdy nazývané jako repetitivní strečink. Hmity v krajní poloze, dopružení, jsou pohyby aktivní, dynamické. Jejich podstatou je opakované měkké hmitání, pérování, při němž se dosahuje pomocí setrvačné síly a pružnosti částí těla na krátkou dobu krajní polohy. Lze je kombinovat s výdrží nejméně $5 \mathrm{~s} \mathrm{v}$ krajní poloze.

Ve zdravotní tělesné výchově a v gymnastice se užíaá vedený „legátový“ pohyb s výdrží v krajní poloze. $\mathrm{V}$ průběhu celistvého pohybu jsou v kontrakci svaly provádějící pohyb (agonisté), ale i svaly s opačnou funkcí udržující a kontrolující směr pohybu (antagonisté). Nejedná se o metodu přinášející maximální protahovací účinky, ale jedná se o jakýsi kompromis mezi posilováním a protahováním v rámci dynamického cvičení. Obdobný typ pohybu je součástí cvičení poweryogy.

\section{METODIKA}

Výzkumu se zúčastnilo 14 studentek $(\mathrm{n}=14)$ Pedagogické fakulty Univerzity J. E. Purkyně v Ústí nad Labem ve studijním oboru tělesná výchova a sport. Jednalo se o zdravé jedince bez oslabení hybného systému. Průměrný věk probandů byl $21,1 \pm 1,1$ let, průměrná výška $169,3 \pm 5,9 \mathrm{~cm}$ a hmotnost $60,6 \pm 6,1 \mathrm{~kg}$.

Kloubní flexibilita byla vyhodnocena u hamstringů dominantní dolní končetiny jako ve studii Silveira, Sayersa, Waddingtona (2011), přičemž dominantní dolní končetina byla určena testem pěti kopů o zed' (Chan, Hong, \& Robinson, 2001). Hamstringy jsou požadovány za jednu z nejčastěji zkrácených svalových skupin. Thurzová (1998) řadí zkrácené hamstringy a m. triceps surae mezi nejčastější funkční svalovou poruchu.

Pro hodnocení flexibility byla zvolena modifikovaná Lassegueova zkouška (dále SLR „Straight leg raise“), kde se hodnotí dosažená poloha dolní končetiny - za normalitu se považuje přednožení blízko svislé polohy (Skopová \& Zítko, 2005). Základní polohou je leh pokrčmo nedominantní dolní končetinou, přednožit dominantní dolní končetinu, paže zafixovány zkřižmo na ramenou, fixovaná pánev (obrázek 1). V lehu pokrčmo bylo pro dosažení úhlu 90 stupňů mezi bércem a stehnem využito goniometrie. Modifikace zkoušky zajistila fixaci pánve k podložce. Pro účely naši práce byla použita intervence dynamického a statického strečinku a vyhodnocení bylo provedeno pomocí modifikované Lassegueovy zkoušky provedené tahem a švihem před a po aplikaci vybraného způsobu strečinku.

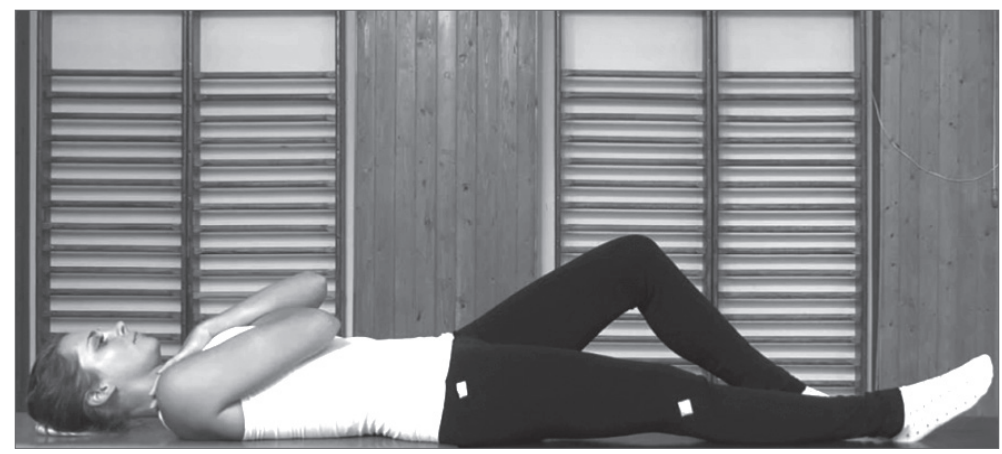

Obrázek 1: Výchozí pozice před realizací pohybu 


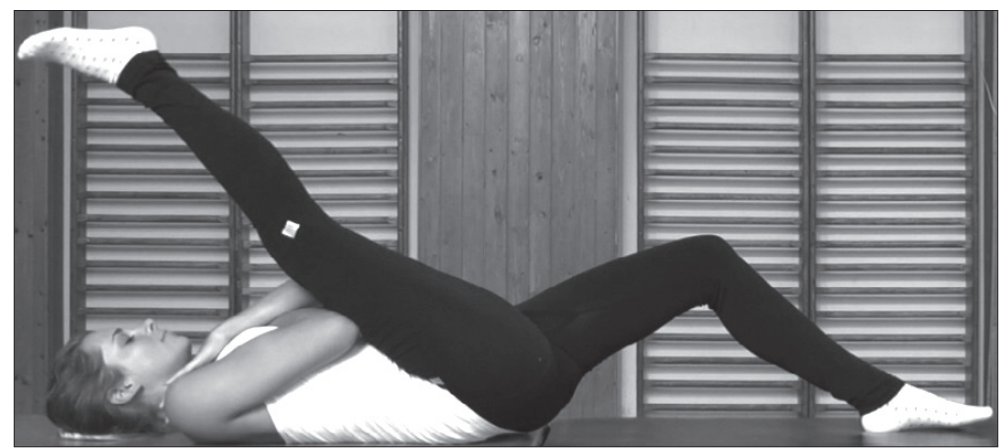

Obrázek 2: Maximální rozsah pohybu švihem

Testování se uskutečnilo v prvním a druhém týdnu měsíce října roku 2014. V prvním týdnu byly sledovány proměnné při použití statického strečinku, ve druhém týdnu při použití dynamického strečinku. Test SLR byl v daném týdnu proveden nejprve tahem a po dvoudenním odpočinkovém režimu byl proveden švihem vždy před a po aplikaci vybraného způsobu strečinku. U švihového způsobu provedení SLR bylo přednožení provedeno normální či zvýšenou rychlostí (Měkota, 2005), kdy krajní polohy bylo dosaženo švihem (obrázek 2) či hmitem (provádí se měkce), s možností krátké výdrže. U provedení tahem bylo rozsahu v kloubu dosaženo povlovným pomalým pohybem s výdrží v krajní poloze $2 \mathrm{~s}$.

Před testováním studentky provedly zahřátí obsahující lehkou chůzi po dobu 2 minut a mírný poklus se zapojenými pohyby paží po dobu 3 minut. Následovalo vstupní měření SLR tahem, vlastní protažení statickým strečinkem a vyhodnocení rozsahu pohybu v kloubně svalové jednotce SLR tahem po aplikaci strečinku. Po dvou dnech klidového režimu stejným postupem bylo SLR provedeno švihem. Po týdnu ve stejném čase, ve stejnou denní dobu a na stejném místě se měření opakovalo s aplikací protahovacích cvičení dynamickým strečinkem ve stejném časovém sledu jako u aplikace statického strečinku. Soubor protahovacích cviků a počty opakování (tabulka 1) byly upraveny pro potřeby výzkumu podle studie Silveira, Sayersa, Waddingtona (2011).

V rámci odpočinkového režimu testované osoby neprováděly žádný jiný program pro rozvoj kloubní pohyblivosti a nepožily stimulující ani jiné omamné látky. Testované osoby byly předem seznámeny se všemi kroky a postupy, se kterými se v průběhu výzkumu setkají. Podpisem informovaného souhlasu potvrdily účast ve studii a akceptování předem definovaných podmínek.

Tabulka 1: Popis cviků a počty opakování pro zvolený způsob strečinku u dominantní dolní končetiny volně přeloženo (Silveira, Sayers, \& Waddington, 2011)

\begin{tabular}{|l|c|l|c|}
\hline \multicolumn{2}{|c|}{ Cvik počet opakování } & \multicolumn{2}{c|}{ Dynamický strečink } \\
\hline \multicolumn{1}{|c|}{ Cvik počet opakování } \\
\hline Předklon v sedu & výdrž $15 \mathrm{~s}, 5 \times$ & Stoj zánožný P, přednožit P & $7-8 \times, 5$ sérií \\
\hline Pauza & $10 \mathrm{~s}$ & Pauza & $10 \mathrm{~s}$ \\
\hline Překlon ve stoji - „vyvěsit“ paže & výdrž $15 \mathrm{~s}, 5 \times$ & $\begin{array}{l}\text { Stoj přednožný zkřižmo P } \\
\text { dovniťr, unožit P s vytočením } \\
\text { špičky směrem nahoru }\end{array}$ & $7-8 \times, 5$ sérií \\
\hline Pauza & $10 \mathrm{~s}$ & Pauza & $10 \mathrm{~s}$ \\
\hline $\begin{array}{l}\text { Leh pokrčmo L, přednožit P } \\
\text { a přitáhnout k trupu pomocí } \\
\text { švihadla }\end{array}$ & výdrž $15 \mathrm{~s}, 5 \times$ & „Jizda na kole“ & $7-8 \times, 5$ sérií \\
\hline Pauza & $10 \mathrm{~s}$ & \multicolumn{1}{|l}{} \\
\hline $\begin{array}{l}\text { Mezi opakováním cviku u statického strečinku } \\
\text { vždy pauza } 10 \mathrm{~s} .\end{array}$ & $\begin{array}{l}\text { Mezi opakováním série u dynamického strečinku } \\
\text { vždy pauza } 10 \mathrm{~s} .\end{array}$ \\
\hline
\end{tabular}


Pro kinematickou analýzu byly použity reflexní elastické pásky umístěné na mediálním epikondylu kolenního kloubu a velkém trochanteru femuru. Vyhodnocení kloubní pohyblivosti a protaŽení svalů bylo provedeno pomocí digitální kamery (multiformátová AVCHD kamera Panasonic AG-HMC 41 s rychlostí snímkování 50 snímků/sec a zápisem 720/50 p). K zajištění objektivity měření byl střed objektivu kamery umístěn ve výšce $115 \mathrm{~cm}$ a vzdálen od testovaných osob $230 \mathrm{~cm}$. TO při měření ležely na $80 \mathrm{~cm}$ vysoké podložce. Videozáznam byl vyhodnocen pomocí softwaru Dartfish Team Pro Data. Spojnice mezi body mediálního epikondylu kolenního kloubu a velkého trochanteru femuru byla považována za referenční vzdálenost určující vztah mezi vertikálou procházející z velkého trochanteru femuru směrem vzhůru a maximálním dosaženým bodem epikondylu. Úhel byl zjištěn z vertikály a kolmicí procházející epikondylem. ROM (cm) byl vypočítáván jako vzdálenost mezi vertikálou a epikondylem kolenního kloubu.

Statistické zpracování dat bylo vyhodnoceno programem Statistica 6.1. Shapiro Wilks W test prokázal, že data byla normálně rozdělena. $Z$ tohoto důvodu bylo pro zjištění statistické významnosti $(\mathrm{p} \leq 0,05)$ využito T-testu pro závislé soubory, kde byly porovnány průměrné hodnoty a byla dopočítána věcná významnost.

\section{VÝSLEDKY}

Ve výsledkové části práce byly nejprve sledovány rozdíly mezi zjištěnými hodnotami při použití intervence statického strečinku. Následně byla pozornost zaměřena na ověření rozdílu hodnot při použití intervence dynamického strečinku. Výsledné hodnoty jsou prezentovány v tabulce 2.

Tabulka 2: Rozdíly v rozsahu pohybu před a po intervenci statického a dynamického strečinku

\begin{tabular}{|l|c|c|c|c|c|c|c|}
\hline Proměnné & Před I (ø) & SD & Po I (ø) & SD & T & P & $\boldsymbol{\omega}^{2}$ \\
\hline ST (1. fáze) & 7,857 & 6,503 & 8,929 & 6,498 & $-0,977$ & 0,356 & 0,003 \\
\hline Sธ̌ (2. fáze) & 18,214 & 7,443 & 19,571 & 6,947 & $-1,324$ & 0,208 & 0,051 \\
\hline DT (1. fáze) & 8,000 & 6,884 & 19,143 & 6,893 & $-1,865$ & 0,085 & 0,151 \\
\hline DŠ (2. fáze) & 19,142 & 6,893 & 20,857 & 7,304 & $-4,305$ & $\mathbf{0 , 0 0 1}$ & 0,556 \\
\hline
\end{tabular}

Vysvětlivky: ST - statický strečink (SLR provedeno tahem), SŠ - statický strečink (SLR provedeno švihem), DT - dynamický strečink (SLR provedeno tahem), DŠ - dynamický strečink (SLR provedeno švihem), I - intervence statického či dynamického strečinku, $\mathrm{SD}$ - směrodatná odchylka, $\mathrm{t}$ - hodnota T-testu, $\mathrm{p}$ - pravděpodobnost chyby při zamítnutí $\mathrm{H}_{0}$, $\omega^{2}-$ hodnota effect size

Z výsledků vyplývá, že nebyl zjištěn významný rozdíl ve vzdálenosti vyjádřené v centimetrech před použitím intervence a po použití intervence statického strečinku, kdy byl pohyb veden tahem $\left(\mathrm{p}=0,356, \omega^{2}=0,003\right)$. Podobný trend byl při využití statického strečinku zaznamenán i v př́padě pohybu u SLR švihem $\left(p=0,208, \omega^{2}=0,051\right)$.

Ani v př́ipadě dynamického strečinku, kdy byl pohyb proveden tahem, nebyl zjištěn významný rozdíl při porovnání vzdáleností před a po jeho intervenci $\left(\mathrm{p}=0,085, \omega^{2}=0,151\right)$. Statisticky a věcně významný rozdíl byl zjištěn mezi hodnotami před a po intervenci dynamického strečinku, kde byl pohyb při SLR veden švihem $\left(p=0,001, \omega^{2}=0,556\right)$. 
Tabulka 3: Rozdíl v rozsahu pohybu po intervenci statického a dynamického strečinku

\begin{tabular}{|c|c|c|c|c|c|c|c|}
\hline Proměnné & ST po I (ø) & SD & DT po I (ø) & SD & T & P & $\boldsymbol{\omega}^{2}$ \\
\hline ST vs. DT & 8,929 & 6,498 & 19,143 & 6,893 & $-1,059$ & 0,309 & 0,009 \\
\hline Proměnné & SŠ po I (ø) & SD & DŠ po I (ø) & SD & T & P & $\boldsymbol{\omega}^{2}$ \\
\hline SŠ vs. DŠ & 19,571 & 6,947 & 20,857 & 7,304 & $-1,953$ & 0,073 & 0,167 \\
\hline
\end{tabular}

Vysvětlivky: ST - statický strečink (SLR provedeno tahem), SŠ - statický strečink (SLR provedeno švihem), DT - dynamický strečink (SLR provedeno tahem), DŠ - dynamický strečink (SLR provedeno švihem), I - intervence statického či dynamického strečinku, SD - směrodatná odchylka, $\mathrm{t}$ - hodnota T-testu, $\mathrm{p}$ - pravděpodobnost chyby při zamítnutí $\mathrm{H}_{0}$, $\omega^{2}$ - hodnota effect size

V tabulce 3 jsou prezentovány hodnoty rozsahu pohybu zjištěného vždy po intervenci statického či dynamického strečinku. Porovnávány byly zvlášt vzdálenosti při pohybu tahem a švihem. Nebyl zjištěn významný rozdíl v rozsahu pohybu statického vs. dynamického strečinku, kdy byl pohyb při SLR realizován tahem $\left(\mathrm{p}=0,309, \omega^{2}=0,009\right)$. Stejně se projevil vztah statického vs. dynamického strečinku, kdy byl pohyb při SLR uskutečněn švihem $\left(p=0,073, \omega^{2}=0,167\right)$.

\section{DISKUZE}

Studie posuzující krátkodobý efekt statického a dynamického strečinku na protažení hamstringů u zdravých jedinců a jedinců po předchozím zranění hamstringů prokázala, že u obou sledovaných skupin intervence zahřátí i statického strečinku signifikantně zvýšila protažení hamstringů, zatímco intervence dynamického strečinku ne (O’Sullivan, Murray, \& Sainsbury, 2009).

Bandy, Irion, a Briggler (1998) ve výsledcích své studie uvádí, že aplikace statického strečinku i dynamických cvičení vede ke zlepšení rozsahu pohybu a vyššímu protažení hamstringů, přičemž 30 s statický strečink vykazuje dvakrát vyšší efekt zvýšení úrovně kloubní pohyblivosti než technika DROM (dynamic range of motion - „dynamická cvičení ke zvýšení pohyblivosti“).

Studie od Rosembauma a Henninga (1995) dospěla k závěru, že není vhodné aplikovat pouze statické strečinkové stereotypy, jelikož nelze vyloučit jejich „potenciálně nepříznivý účinek na svalovou výkonnost“.

Výzkumné práce prokazují, že dynamický strečink sice vede k rozvoji optimálního rozsahu pohyblivosti nezbytného pro všechny druhy sportů (Alter, 1999), avšak jedná se o nejdiskutovanější strečinkovou techniku spojovanou s nejvyšším výskytem bolestivosti svalů a poraněními. Jak uvádí Novotná (2006), dynamický strečink a jeho modifikace se někdy dostává do rozporu s fyziologickými zákonitostmi, protože může dojít ke spuštění napínacího reflexu.

Pro zvýšení dynamické pohyblivosti Zachazewski (1990) doporučuje postupný program zvyšování rychlosti a rozvoje pohyblivosti po předchozím rozcvičení. Kurz (1994) zpochybňuje teorii provádění statického strečinku po počátečním rozcvičení, protože statické strečinkové cvičení je před tréninkem tvořeným dynamickými pohyby kontraproduktivní.

Vlivem intervence rozcvičení na pohybový čas výpadu v šermu se zabývali Balkó, Balkó, Cihlář, Týnková, a Hendl (2013). V jejich studii nebyl zjištěn rozdíl v rychlosti výpadu zjištěné ve fázi bez rozcvičení, se statickým rozcvičením a s využitím dynamického rozcvičení.

Statický strečink je podle Měkoty (2005) metodou šetrnější a účinnější než dynamické protahování, protože je při něm menší pravděpodobnost ruptur svalových vláken.

Studie Silveira, Sayersa, Waddingtona (2011) uvádí, že statický strečink nezlepšil dynamickou flexibilitu hamstringů, nicméně dynamický strečink zlepšil dynamickou i statickou flexibilitu hamstringů, což má vliv na specifičnost protahování ve sportu.

Výzkumy ukázaly, že balistický strečink není nejvhodnější jak z hlediska ovlivnění rozvoje pohyblivosti, tak z důvodu prevence zranění. Švihové pohyby lze však v procesu tréninku využít ve specifických cvičeních, ale musí být vybrány a aplikovány se zřetelem k obsahu sportovní př́pravy a s ohledem na individuální předpoklady sportovce. 
V předložené studii se projevil pouze rozdíl mezi hodnotami zjištěnými před intervencí dynamického strečinku a po jeho intervenci, kdy byl pohyb prováděn švihem $\left(\mathrm{p}=0,001, \omega^{2}=0,556\right)$. $\mathrm{Z}$ uvedeného lze usuzovat, že dynamický strečink může pozitivně ovlivnit rozsah pohybu. Tato skutečnost může být zohledněna při provozování sportovních disciplín, ve kterých tvoři švihová a dynamická cvičení podstatnou složku sportovního výkonu. Na výsledky práce, kde nebyly objeveny rozdíly, mohl mít vliv malý rozsah výzkumného souboru.

\section{ZÁVĚRY}

Z výsledků studie lze usuzovat na vliv rozdílných technik protažení na úroveň flexibility ve zvolené kloubně-svalové jednotce. Výsledky práce mohou být uplatněny trenéry různých sportovních disciplín (gymnastika, úpolové sporty, apod.), kde lze rozsah kloubní pohyblivosti v tréninku či před soutěží považovat za důležitou komponentu sportovního výkonu. Podobná problematika může být sledována například při využití PNF ve fyzioterapii či rehabilitaci.

\section{Literatura}

Alter, J. (1999). Strečink, 311 protahovacích cviků pro 41 sportů. Praha: Grada Publishing.

Balkó, Š., Balkó, I., Cihlář, D., Týnková, H., \& Hendl, J. (2013). Vliv rozcvičení na jednoduchou reakční dobu a pohybový čas při výpadu v šermu. Studia Kinantrhropologica 14(2), 77-84.

Bandy, W. D., \& Irion, J. M. (1994). The effect of time on static stretch on the flexibility of the hamstring muscles. Physical Therapy, 47(9), 845-852.

Bandy, W., Irion, J., \& Briggler, M. (1998). The effect of static stretch and dynamic range of motion training on the flexibility of the hamstring muscles. J Orthop Sports Phys Ther, 27(4), 295-300.

Bartůňková, S. (2007). Fyziologie člověka a tělesných cvičení. Učební texty pro studenty fyzioterapie a studia tělesná výchova a pracovní výchova zdravotně postižených. Praha: Karolinum.

Buzková, K. (2006). Strečink: 240 cvičení pro dokonalé protažení celého těla. Grada Publishing.

Dovalil, J. et al. (2002). Výkon a trénink ve sportu. Praha: Olympia.

Havel, Z., \& Hnízdil, J. (2010). Rozvoj a diagnostika koordinačních a pohyblivostních schopností. Banská Bystrica: PF Univerzita Mateja Bela.

Máček, M., \& Radvanský, J. (2011). Fyziologie a klinické aspekty pohybové aktivity. Praha: Galén.

Chan, S., Hong, Y., \& Robinson, P. (2001). Flexibility and passive resistence of the hamstrings of young adults using two different static stretching protocols. Scand J Med Sci Sports, 11, 81-86.

Kabešová, H. (2011). Rozvoj flexibility jako komponenty zdravotně orientované zdatnosti. Studia Sportiva, 5(1), 75-83.

Kurz, T. (1994). Stretching scientifically: A quide to flexibility training. 3rd ed. Island Pond, VT: Stadion.

Mihule, J., \& Štastná, D. (1993). Rytmická gymnastika. Praha: Karolinum.

Měkota, K. (2005). Koordinační schopnosti a flexibilita. In K. Měkota, \& J. Novosad (Eds.), Motorické schopnosti, (pp. 55-107). Olomouc: UP.

Nelson, A. G., \& Kokkonen, J. (2009). Strečink-na anatomických základech. Grada Publishing as.

Novotná, V. (2006). Flexibilita. In V. Novotná, I. Čechovská, \& V. Bunc, V. (Eds.), Fit programy pro ženy (pp. 32-36). Praha: Grada Publishing.

O'Sullivan, K., Murray, E., \& Sainsbury, D. (2009). The effect of warm-up, static stretching and dynamic stretching on hamstring flexibility in previously injured subjects. BMC Musculoskelet Disord, 16, 10-37.

Roi, G. S., \& Bianchedi, D. (2008). The science of fencing: implications for performance and injury prevention. Sports Medicine, 38(6), 465-4871.

Rosembaum, D., \& Henning, E. (1995). The influence of stretching and warm-up exercises on Achilles tendon reflex activity. Journal of Sports Science, 13(6), 481-490.

Shier, S. I. (2004). Does stretching improve performance? A systematic and critical review of the literature. Clinical Journal of Sport Medicine, 14(5), 269-273.

Silveira, G., Sayers, M., \& Waddington, G. (2011). Effect of dynamic versus static stretching in the warm-up on hamstring flexibility. The Sport Journal, 14(1).

Skopová, M., \& Zítko, M. (2005). Základní gymnastika. Praha: Karolinum.

Šebej, F. (2001). Strečink. Bratislava: TIMY.

Thurzová, E. (1998). Skrátené flexory kolena jako najčastejšia funkčná svalová porucha detí a mládeže. Acta.fac. Educ. Phys.,39, 113-142.

Tůma, Z., Appelt, K., Libra, J.,\& Libra, M. (1988). Sportovní gymnastika I. díl. Učební text pro trenéry III. a ll. tř́dy. Praha: Olympia. Ylinen, J. (2008) Stretching therapy for sport and manual therapies. New York: Elsevier.

Zachazewski, J. (1990). Flexibility for sports. In B. Sanders (Ed.), Sports physical therapy, (pp. 201-238). Norwalk, CT: Appleton \& Lange. 